\title{
Factors Associated with the Occurrence of Anemia in Pregnant Women at the Anutapura Hospital in Palu
}

\author{
Ni Nyoman Elfiyunai' ${ }^{1}$ Mulyati M.Tahir ${ }^{2}$, Farlina ${ }^{3}$ \\ 1,2,3 Universitas Indonesia Timur \\ Email : elfiyunai06@gmail.com
}

\begin{abstract}
Abstrak
Anemia dianggap sebagai masalah kesehatan masyarakat karena prevalensinya yang masih tinggi. Anemia dapat memberikanakibat buruk terhadap ibu hamil seperti mudah terserang penyakit,Berat Bayi Lahir Rendah (BBLR), pengaruh pada kemampuan kerja,bahkan pada anemia berat dapat mengakibatkan kematian. Rumusan masalah pada penelitian ini adalah apakah ada hubungan paritas, umur ibu, konsumsi tablet Fe, jarak kehamilan dan pemanfaatan pelayanan antenatal dengan kejadian anemia pada ibu hamil di Rumah Sakit Umum Anutapura Palu. Tujuan penelitian ini adalah mengetahui faktor-faktor yang berhubungan dengan kejadian anemiapada ibu hamildi Rumah Sakit Umum Anutapura Palu. Jenis penelitian ini digunakan adalah penelitian observasional dengan pendekatan cross sectional study. Variabel independen pada penelitian ini yaitu paritas, umur, jarak kehamilan, dan pemanfaatan pelayanan antenatal care, variabel dependen yaitu anemia pada ibu hamil.Analisis data dengan menggunakan analisis univariat dan bivariat serta uji statistik chi-square dan multivariat. Penarikan sampel dengan menggunakan metode Purposive sampling. Sampel sebanyak 87 responden. Ada hubungan paritas ( $p=0.003)$, umur ibu $(p=0.005)$, jarak kehamilan $(p=0,001)$ dan pemanfaatan pelayanan antenatal $(p=0.002)$ dengan kejadian anemia pada ibu hamil di Rumah Sakit Umum Anutapura Palu. Faktor konsumsi tablet Fe yang paling dominan dimana tingkat nilai Exp (B) 1,594 pada Cl $95 \%$ dan nilai lower limit = 0,585 dan upper limit $=4,341$ dengan tingkat kemaknaan =0,000. berhubungan dengan kejadian anemia pada ibu hamil di Rumah Sakit Umum Anutapura Palu. Saran kepada rumah sakit khususnya petugas kesehatan untuk memberikan penyuluhan pada ibu hamil tentang pentingnya kunjungan antenatal care minimal 4 kali selama hamil, agar dapat memenuhi kebutuhan tablet zat besi selama kehamilan.
\end{abstract}

Kata Kunci : konsumsi tablet Fe, jarak kehamilan, anemia

Abstract
Anemia is considered a public health problem because its prevalence is still high. Anemia can give bad consequences to pregnant women such as susceptible to disease, Low Birth Weight (LBW), influence on workability, even on severe anemia can result in death. The formulation of the problem in this study is whether there is a relationship of parity, maternal age, consumption of Fe tablets, a distance of pregnancy and utilization of antenatal care with the incidence of anemia in pregnant women at Anutapura General Hospital, Palu. The purpose of this study was to determine the factors associated with the incidence of maternal mortality in Anutapura General Hospital, Palu. This type of research is an observational study with a cross-sectional study approach. The independent variables in this study are parity, age, pregnancy distance, and the use of antenatal care services, the dependent variable is anemia in pregnant women. Data analysis using univariate and bivariate analysis and chi-square and multivariate statistical tests. Sampling using the Purposive sampling method. Samples were 87 respondents. There was a relationship of 
parity $(p=0.003)$, maternal age $(p=0.005)$, pregnancy distance $(p=0.001)$ and utilization of antenatal services $(p=0.002)$ with the incidence of anemia in pregnant women at Anutapura General Hospital, Palu. The most dominant factor of Fe tablet consumption where the level of $\operatorname{Exp}(B)$ value is 1.594 at $95 \% \mathrm{Cl}$ and lower limit value $=0.585$ and upper limit $=4.341$ with a significance level $=0.000$. related to the incidence of anemia in pregnant women at Anutapura General Hospital, Palu. Advice to hospitals, especially health workers to provide counseling to pregnant women about the importance of antenatal care visits at least 4 times during pregnancy, to meet the needs of iron tablets during pregnancy.

Keywords: consumption of Fe tablets, pregnancy distance, anemia

Article info:

Article submitted on September 20, 2019

Articles revised on October 29, 2019

Articles received on November 18, 2019

DOI: http://dx.doi.org/10.21927/jnki.2019.7(3).136-145

\section{INTRODUCTION}

Anemia during pregnancy is an important health problem to improve the health of the community with public health. Concerning maternal and child health, anemia problems include common nutritional problems in developing countries, including Indonesia. Anemia during pregnancy is the most important health problem to improve public health about maternal and child health. Anemia is one of the factors that become a success indicator of a nation's health development, which describes socio-economic capabilities in fulfilling the quality and quantity of people's nutrition (3).

Based on data from the World Health Organization (WHO) in 2010 that anemia in pregnant women ranged from $20-89 \%$ and set $\mathrm{Hb} 11 \mathrm{gr} \%$ as a basis. In developing countries including Indonesia, the infant mortality rate and the percentage of anemia during pregnancy are the most sensitive indicators that describe health status, especially maternal health in infants. According to the Survey Kesehatan Nasional (SKN) in 2010 the incidence of anemia in pregnant women was $36.1 \%$. This condition shows that anemia is quite high in Indonesia. It was reported that the prevalence of anemia in Indonesia was 705 . This means that 7 out of 10 pregnant women suffer from anemia. Based on the 2009 population survey, it is estimated that for all age groups, two hundred million people suffer from anemia. This means that nationally $50 \%$ of Indonesia's population is at risk of suffering from anemia.

A pregnant woman is a group that is vulnerable to nutritional problems, especially anemia due to iron (Fe) deficiency. Results of Survey Kesehatan Rumah Tangga (SKRT) in Indonesia from year to year showed the level of anemia of pregnant women was $73.3 \%$ in 2006 ; $63.5 \%$ in $2012 ; 50.9 \%$ in 2008 . While in Central Sulawesi based on SKRT 2012, the irondeficiency anemia reached $24.5 \%$ (2).

The high rate of maternal mortality still becomes a public health problem in various countries, especially in developing countries including Indonesia. Around $15-20 \%$ of maternal mortality is directly or indirectly related to anemia. Anemia is the biggest and most difficult micronutrient problem on the whole agenda (Soekirman 2000 in Darlina 2003). Most anemia in pregnant women is anemia due to iron deficiency. Currently, it is estimated that every year around 4 million pregnant women and nursing mothers suffer from anemia that mostly caused by iron deficiency (8). 
Anemia in pregnant women is associated with several factors, for example, knowledge, where there is a lack of knowledge of pregnant women regarding food containing iron essential, education level, parity, and antenatal use. The optimal use of antenatal care will improve the health status of pregnant women and will motivate them to consume foods that are rich in $\mathrm{Fe}$.

The medical record data of the AnutapuraPalu Hospital in 2012 showed the number of pregnant women who had their pregnancies in 2012 as many as 173 pregnant women with several anemia cases as 97 pregnant women. While in 2013, there are 82 of 158 pregnant women suffering from anemia and 62 of 160 pregnant women suffering from anemia in 2014.

\section{MATERIALS AND METHODS}

This research is an observational study with a cross-sectional study approach, where data on dependent and independent variables will be collected at the same time to obtain information about the relationship of several factors to the incidence of anemia in pregnant women at the Anutapura Hospital in Palu. The population in this study were all pregnant women who visited the Anutapura Hospital in Palu.

Primary data was obtained through the measurement of $\mathrm{Hb}$ levels using the Chyanmethimoglobin method and filling in questionnaires distributed to pregnant women. Data analysis used was univariate using frequency distribution and single percentage, Bivariate used was chi-square test and multivariate using regression logistic analysis.

\section{RESULTS AND DISCUSSION}

\section{Univariate Analysis}

\section{Anemia incidence}

Table 1 shows that based on the Hb levels of respondents, there were 57 (65.5\%) pregnant women who were anemic, and 30 (34.5\%) respondents did not experience anemia.
Table 1. Distribution of Respondents Basedonthe

Occurrence of Anemia in pregnant women in Anutapura Hospital

\begin{tabular}{ccc}
\hline Hb Level & $(\mathbf{n})$ & $\mathbf{( \% )}$ \\
\hline Anemia & 57 & 65,5 \\
Normal & 30 & 34,5 \\
\hline Total & $\mathbf{8 7}$ & $\mathbf{1 0 0}$
\end{tabular}

Source: Primary Data, 2015

\section{Parity}

Table 2 shows that according to the parity of respondents, pregnant women with highrisk parity were $40(46.0 \%)$ respondents and pregnant women with low-risk parity were 47 $(54.0 \%)$ respondents.

Table 2. Distribution of Pregnant Women who Have Pregnancy According to Paritas at Anutapura Hospital

\begin{tabular}{ccc}
\hline Parity & (n) & (\%) \\
\hline High Risk & 40 & 46,0 \\
Low Risk & 47 & 54,0 \\
\hline Total & $\mathbf{8 7}$ & $\mathbf{1 0 0}$
\end{tabular}

Source: Primary Data, 2015

\section{Maternal Age}

Table 3 shows that according to the respondents'maternal age, pregnant women with high-risk maternal age were 37 (42.5\%) respondents and pregnant women with low-risk maternal age were $50(57.5 \%)$ respondents.

Table 3. Distribution of Pregnant Women who check the Pregnancy According to Maternal Age at Anutapura Hospital

\begin{tabular}{ccc}
\hline Maternal Age & (n) & $\mathbf{( \% )}$ \\
\hline High Risk & 37 & 42,5 \\
Low Risk & 50 & 57,5 \\
\hline Total & $\mathbf{8 7}$ & $\mathbf{1 0 0}$ \\
\hline
\end{tabular}

Source: Primary Data, 2015

\section{Consumption of Fe tablets}

Table 4 shows that according to respondents' Fe tablet consumption, pregnant women with less $\mathrm{Fe}$ tablet consumption as much as 49 $(56.3 \%)$ respondents and pregnant women with sufficient Fe tablet consumption as many as 38 $(43.7 \%)$ respondents. 
Table 4. Distribution of Pregnant Women who check the Pregnancy According to Fe Tablet Consumption at Anutapura Hospital

\begin{tabular}{ccc}
\hline Fe Tablet Consumption & (n) & (\%) \\
\hline Less & 49 & 56,3 \\
Sufficient & 38 & 43,7 \\
\hline Total & $\mathbf{8 7}$ & $\mathbf{1 0 0}$ \\
\hline
\end{tabular}

Source: Primary Data, 2015

\section{Pregnancy Distance}

Table 5 shows that according to the respondents' pregnancy distance, pregnant women with a high-risk pregnancy distance were $45(51.7 \%)$ respondents and pregnant women with a low-risk pregnancy distance were 42 $(48.3 \%)$ respondents.

Table 5. Distribution of Pregnant Women who check the Pregnancy According to Pregnancy Distance at Anutapura Hospital

\begin{tabular}{ccc}
\hline Pregnancy Distance & (n) & (\%) \\
\hline High Risk & 45 & 51,7 \\
Low Risk & 42 & 48,3 \\
\hline Total & $\mathbf{8 7}$ & $\mathbf{1 0 0}$
\end{tabular}

Source: Primary Data, 2015

\section{Use of antenatal services}

Table 6 shows that according to the utilization of the respondent's antenatal services, pregnant women with less utilization of antenatal care were 46 (52.9\%) respondents and pregnant women with sufficient use of antenatal care were $41(47.1 \%)$ respondents.

Table 6. Distribution of Pregnant Women who check the Pregnancy According to the Use of Antenatal Service at Anutapura Hospital

\begin{tabular}{ccc}
\hline Use of Antenatal Service & (n) & (\%) \\
\hline Less & 46 & 52,9 \\
Sufficient & 41 & 47,1 \\
\hline Total & $\mathbf{8 7}$ & $\mathbf{1 0 0}$ \\
\hline
\end{tabular}

Source: Primary Data, 2015

\section{Bivariate Analysis}

Relationship between parity and anemia in pregnant women

Table 7 shows that from 87 respondents, pregnant women who had high-risk parity were
$40(46.0 \%)$ respondents, who had anemia were $27(67.5 \%)$ respondents and who had not been $13(32.5 \%)$ respondents. Whereas those with low-risk parity were 47 (54.0\%) respondents, who had anemia were $30(63.8 \%)$ respondents and who had not been $17(36.2 \%)$ respondents.

The results of relationship analysis using the Chi-Square test of 1 and $\alpha=0,05$ were obtained $p=0,003$ where $p<\alpha$ which means statistically the null hypothesis is rejected and the alternative hypothesis is accepted so that there is a significant relationship between parity and the incidence of anemia in pregnant women at the Anutapura Hospital in Palu.

Table 7. Relationship between Parity and the incidence of anemia in pregnant women at Anutapura Hospital in Palu

\begin{tabular}{cccccccc}
\hline \multirow{3}{*}{ Parity } & \multicolumn{4}{c}{ Anemia } & \multicolumn{2}{c}{ Total } & \multirow{2}{*}{$\mathbf{P}$} \\
\cline { 2 - 6 } & \multicolumn{2}{c}{ Yes } & \multicolumn{2}{c}{ No } & & \\
\cline { 2 - 6 } & $\mathbf{n}$ & $\mathbf{\%}$ & $\mathbf{n}$ & $\mathbf{\%}$ & $\mathbf{n}$ & $\mathbf{\%}$ & \\
\hline High Risk & 27 & 67,5 & 13 & 32,5 & 40 & 46,0 & \\
Low Risk & 30 & 63,8 & 17 & 36,2 & 47 & 54,0 & 0,003 \\
\hline Total & $\mathbf{5 7}$ & $\mathbf{6 5 , 5}$ & $\mathbf{3 0}$ & $\mathbf{3 4 , 5}$ & $\mathbf{8 7}$ & $\mathbf{1 0 0}$ & \\
\hline
\end{tabular}

Source: Primary Data, 2015

\section{Relationship between age and anemia in pregnant women}

Table 8 shows that from 87 respondents, pregnant women who had high-risk age were $37(42.5 \%)$ respondents, those who had high risk age with anemia were 26 (70.3\%) respondents and without anemia were 11 $(29.7 \%)$ respondents. Whereas those who had low-risk age were 50 (57.5\%) respondents, those who had low risk age with anemia were $31(62.0 \%)$ respondents and without anemia were $19(38.0 \%)$ respondents.

The results of relationship analysis using the Chi-Square test of 1 and $\alpha=0,05$ were obtained $p=0,005$ where $p<\alpha$ which means statistically the null hypothesis is rejected and the alternative hypothesis is accepted so that there is a significant relationship between the age of the 
mother and the incidence of anemia in pregnant women at the Anutapura Hospital in Palu.

Table 8. Relationship between Age and Anemia Occurrence in Pregnant Women atAnutapura Hospital

\begin{tabular}{cccccccc}
\hline & \multicolumn{4}{c}{ Anemia } & \multicolumn{2}{c}{ Total } & \multirow{2}{*}{ Age } \\
\cline { 2 - 6 } & \multicolumn{2}{c}{ Yes } & \multicolumn{2}{c}{ No } & & \\
\cline { 2 - 6 } & $\mathbf{n}$ & $\mathbf{\%}$ & $\mathbf{n}$ & $\mathbf{\%}$ & $\mathbf{n}$ & $\mathbf{\%}$ & \\
\hline High Risk & 26 & $\mathbf{7 0 , 3}$ & 11 & 29,7 & 37 & 42,5 & \\
Low Risk & 31 & 62,0 & 19 & 38,0 & 50 & 57,5 & 0,005 \\
\hline Total & $\mathbf{5 7}$ & $\mathbf{6 5 , 5}$ & $\mathbf{3 0}$ & $\mathbf{3 4 , 5}$ & $\mathbf{8 7}$ & $\mathbf{1 0 0}$ & \\
\hline
\end{tabular}

Source: Primary Data, 2015

\section{Relationship between Fe Tablet Consumption and Anemia in Pregnant Women}

Table 9 shows that from 87 respondents, pregnant women who had less consumption of Fe tablets were 49 (56.3\%) respondents, with anemia were $29(59.2 \%)$ respondents and without anemia were 20 (40.8\%) respondents. While those who had sufficient consumption of $\mathrm{Fe}$ tablets were $38(43.7 \%)$ respondents, with anemia were $28(73.7 \%)$ respondents and without anemia were $10(26.3 \%)$ respondents.

The results of relationship analysis using the Chi-Square test of $\mathrm{df}$ (Degree of Freedom) 1 and $\alpha=0,05$ were obtained $p=0,000$ where $p$ $<\alpha$ which means statistically the null hypothesis is rejected and the alternative hypothesis is accepted so that there is a significant relationship between Fe tablet consumption and the incidence of anemia in pregnant women at the Anutapura Hospital in Palu.

Table 9. Relationship between Fe Tablet Consumption and Anemia Occurrence in Pregnant Women atAnutapura Hospital

\begin{tabular}{|c|c|c|c|c|c|c|c|}
\hline \multirow{3}{*}{$\begin{array}{c}\text { Fe tablet } \\
\text { consumption }\end{array}$} & \multicolumn{4}{|c|}{ Anemia } & \multicolumn{2}{|c|}{ Total } & \multirow{3}{*}{$\mathbf{P}$} \\
\hline & \multicolumn{2}{|c|}{ Yes } & \multicolumn{2}{|c|}{ No } & & & \\
\hline & $n$ & $\%$ & $\mathrm{n}$ & $\%$ & $\mathbf{n}$ & $\%$ & \\
\hline Less & 29 & 59,2 & 20 & 40,8 & 49 & 56,3 & \\
\hline Sufficient & 28 & 73,7 & 10 & 26,3 & 38 & 43,7 & 0,000 \\
\hline Total & 57 & 65,5 & 30 & 34,5 & 87 & 100 & \\
\hline
\end{tabular}

Source : Primary Data, 2015

\section{Relationship between Pregnancy Distance and Anemia in Pregnant Women}

Table 10 shows that from 87 respondents, pregnant women who had high risk in pregnancy distance were $45(51,7 \%)$ respondents, with anemia were $27(60,0 \%)$ respondents and without anemia were $18(40,0 \%)$ respondents. While those who had low risk in pregnancy distance were42 $(48,3 \%)$ respondents, with anemia were $30(71,4 \%)$ respondents, and without anemia were $12(28,6 \%)$ respondents.

The results of relationship analysis using the Chi-Square test of df (Degree of Freedom) 1 and $\alpha=0,05$ were obtained $p=0,001$ where $p<$ $\alpha$ which means statistically the null hypothesis is rejected and the alternative hypothesis is accepted so that there is a significant relationship between pregnancy distance and the incidence of anemia in pregnant women at the Anutapura Hospital in Palu.

Table 10. Relationship between Pregnancy Distance and Anemia Occurrence in Pregnant Women at Anutapura Hospital

\begin{tabular}{cccccccc}
\hline \multirow{2}{*}{$\begin{array}{c}\text { Pregnancy } \\
\text { Distance }\end{array}$} & \multicolumn{4}{c}{ Anemia } & \multicolumn{2}{c}{ Total } & \multirow{2}{*}{ Yes } \\
\cline { 2 - 6 } & $\mathbf{n}$ & $\mathbf{\%}$ & $\mathbf{n}$ & $\mathbf{\%}$ & $\mathbf{n}$ & $\mathbf{\%}$ & \\
\hline RisikoTinggi & 27 & 60,0 & 18 & 40,0 & 45 & 51,7 & \\
RisikoRendah & 30 & 71,4 & 12 & 28,6 & 42 & 48,3 & 0,001 \\
\hline Total & $\mathbf{5 7}$ & $\mathbf{6 5 , 5}$ & $\mathbf{3 0}$ & $\mathbf{3 4 , 5}$ & $\mathbf{8 7}$ & $\mathbf{1 0 0}$ & \\
\hline
\end{tabular}

Source : Primary Data, 2015

\section{Relationship between the use of antenatal services and anemia in pregnant women}

Table 11 shows that from 87 respondents, pregnant women withless use of antenatal care were $46(52,9 \%)$ respondents, with anemiawere $34(73,9 \%)$ respondents and without anemia were $12(26,1 \%)$ respondents.While those with sufficient use ofantenatal care were $41(47,1 \%)$ respondents, with anemia were23 $(56,1 \%)$ respondents and without anemia were 18 $(43,9 \%)$ respondents.

The results of relationship analysis using the Chi-Square test of df (Degree of Freedom) 
1 and $\alpha=0,05$ were obtained $p=0,002$ where $p$ $<\alpha$ which means statistically the null hypothesis is rejected and the alternative hypothesis is accepted so that there is a significant relationship betweenthe use of antenatal serviceand the incidence of anemia in pregnant women at the Anutapura Hospital in Palu.

Table 11. Relationship between the use of antenatal service and Anemia Occurrence in Pregnant Women atAnutapura Hospital

\begin{tabular}{|c|c|c|c|c|c|c|c|}
\hline \multirow{3}{*}{$\begin{array}{c}\text { The Use of } \\
\text { Antenatal } \\
\text { Service }\end{array}$} & \multicolumn{4}{|c|}{ Anemia } & \multicolumn{2}{|c|}{ Total } & \multirow{3}{*}{$\mathbf{P}$} \\
\hline & \multicolumn{2}{|c|}{ Yes } & \multicolumn{2}{|c|}{ No } & \multirow[b]{2}{*}{$\mathbf{n}$} & \multirow[b]{2}{*}{$\%$} & \\
\hline & $\mathbf{n}$ & $\%$ & $\mathbf{n}$ & $\%$ & & & \\
\hline Less & 34 & 73,9 & 12 & 26,1 & 46 & 52,9 & \\
\hline Sufficient & 23 & 56,1 & 18 & 43,9 & 41 & 47,1 & 0,002 \\
\hline Total & 57 & 65,5 & 30 & 34,5 & 87 & 100 & \\
\hline
\end{tabular}

Source : Primary Data, 2015

\section{Multivariate Analysis}

Table 12 shows that after statistical tests on all variables together, it turns out that the factors associated with anemia in pregnant women are parity, maternal age, consumption of Fe tablets, distance of pregnancy, and the use of antenatal care. While the most dominant factor associated is consumption of $\mathrm{Fe}$ tablets with the value of $\operatorname{Exp}(\mathrm{B}) 1,594$ in $95 \% \mathrm{Cl}$ and lower limit value $=$ 0,585 and upper limit $=4,341$ with a significance level $=0,000$.

\section{Parity in Pregnant Women}

Parity is the number of deliveries performed by a woman with live births or stillbirths. The number of births can affect the body's metabolic processes. In pregnant women, the need for hydrocytes will increase. So that the higher the level of parity, the more at risk of anemia in pregnant women (7).

Parity is the number of births experienced by a mother, both live and stillborn, but does not include abortion. Complications that can trigger postpartum hemorrhage are found in mothers with the first pregnancy and pregnancy more than the third time. This is because in the first pregnancy, the birth canal has not been tested and the psychological condition has not been stable. While in pregnancy more than the third time, the reproductive system has suffered a setback. Every pregnancy followed by labor will cause abnormalities in the uterus (27).

The results of relationship analysis using the Chi-Square test of $\mathrm{df}$ (Degree of Freedom) 1 and $\alpha=0,05$ were obtained $p=0,003$ where $p$ $<\alpha$ which means statistically the null hypothesis is rejected and the alternative hypothesis is accepted so that there is a significant relationship between parity and the incidence of anemia in pregnant women at the Anutapura Hospital in Palu.

This means that high-risk parity or more than three times of pregnancy are more likely to experience anemia compared to pregnant women with low-risk parity or less than three times pregnancy in pregnant women at the Anutapura General Hospital in Palu.

The high rate of parity in a mother can usually relate to a mother's lack of knowledge about the impact of a high number of pregnancies associated

Table 12. Relationship of Parity, Age, Fe Tablet Consumption, Distance of Pregnancy, and the Use of Antenatal Caretowards the incidence of anemia in pregnant women at Anutapura Hospital in Palu

\begin{tabular}{|c|c|c|c|c|c|c|c|c|}
\hline & \multirow{2}{*}{ B } & \multirow{2}{*}{ S.E. } & \multirow{2}{*}{ Wald } & \multirow{2}{*}{ df } & \multirow{2}{*}{ Sig. } & \multirow{2}{*}{$\operatorname{Exp}(B)$} & \multicolumn{2}{|c|}{ 95.0\% C.I.for EXP(B) } \\
\hline & & & & & & & Lower & Upper \\
\hline Parity(1) & .268 & .486 & .303 & 1 & .582 & .765 & .295 & 1.984 \\
\hline $\operatorname{Age}(1)$ & .224 & .489 & .210 & 1 & .646 & .799 & .306 & 2.084 \\
\hline FeTablet(1) & .466 & .511 & .831 & 1 & .362 & 1.594 & .585 & 4.341 \\
\hline Dist of Pregnancy(1) & .397 & .485 & .669 & 1 & .413 & 1.488 & .574 & 3.852 \\
\hline The use of ANC(1) & .595 & .483 & 1.519 & 1 & .218 & .552 & .214 & 1.421 \\
\hline
\end{tabular}

Source : Primary Data, 2015 
with a lack of information dissemination through counseling about the number of pregnancies that are normally experienced by every woman (9).

The results of this study are supported by the research of SittiAminah (2012) in RSIA Sitti Fatimah Makassar suggesting that parity has a relationship with the incidence of anemia. Anemia can occur in women with high parity associated with the biological condition of the mother and iron intake. Anemia, in this case, is related to a previous pregnancy where if the iron reserves in the body are lacking or minimal, the pregnancy will drain the body's iron supply and will cause anemia in the next pregnancy.

\section{Age in Pregnant Women}

Age is one of the non-modifiable factors. The age intended in this study is related to the implementation of an appropriate pregnancy in every woman whose age is fast carrying out pregnancy tends to be more at risk of the emergence of various health problems compared to the normal gestational age.

A mother's age has a close influence on the development of reproductive organs. This is related to the physiological state of the mother's body in accepting presence and supporting fetal development. A woman entering the age of marriage will experience a certain phase in her life, namely the age of reproduction. In the age of healthy reproduction, it is known that the safe age for pregnancy and childbirth is between 2035 years (23).

The pregnancy that occurs in the risky age category is an unhealthy pregnancy. This is because, in this age, the state of reproductive health and the state of the organs in a woman's body have experienced a decreased ability to deal with pregnancy, especially in the physiological function of the uterus as a reproductive organ. The uterine elasticity has decreased so that it will increase the risk of LBW and complications during labor (14).
Age of pregnant women who are young (less than 20 years) is at high risk of fetal growth because they are in a period of growth that requires a lot of nutrients and then added by pregnancy which means that the calories received must be shared between the mother and the fetus. The development of reproductive instruments is also not entirely optimal. Besides, the psychological burden that must be borne is quite heavy to be pregnant and care for children with minimal knowledge.

The age factor of pregnant women influences the development of female reproductive organs where the age that is safe for pregnant women is aged 20-30 years. The age of pregnancy plays a high role in the occurrence of anemia in pregnant women. This is because with the higher pregnancy, the blood volume will increase which is usually called hydremia or hypervolemia of the blood, so that blood dilution occurs which can cause anemia.

The results of relationship analysis using the Chi-Square test of df (Degree of Freedom) 1 and $\alpha=0,05$ were obtained $p=0,005$ where $p$ $<\alpha$ which means statistically the null hypothesis is rejected and the alternative hypothesis is accepted so that there is a significant relationship between the age of the mother and the incidence of anemia in pregnant women at the Anutapura Hospital in Palu.

This research is supported by the study conducted by Willem at the Cempae Pare-Pare Health Center (2010) which found that age has a relationship with the incidence of anemia. This is also reinforced by the study of SittiAminah at the Fatimah Makassar Hospital who found that under 20 years old and over 35 years old are 9.7 times riskier experiencing anemia compared to pregnant women aged 30-35 years.

\section{Fe Tablet Consumption in Pregnant Women}

Iron enters the body through food. In body tissues, iron is a functional compound such as 
hemoglobin. Ferric iron from food will become ferrous if it is in an acidic state and is reduced so that it is easily absorbed by the intestinal mucosa. In the body, iron is not free but binds to protein molecules to form ferritin namely apoferritin, while iron transport in the form of Ferro binds to proteins forming transfer called apo transferrin in blood plasma called set transfer in.

The results of relationship analysis using the Chi-Square test of df (Degree of Freedom) 1 and $\alpha=0,05$ were obtained $p=0,000$ where $p$ $<\alpha$ which means statistically the null hypothesis is rejected and the alternative hypothesis is accepted so that there is a significant relationship between Fe tablet consumption and the incidence of anemia in pregnant women at the Anutapura Hospital in Palu.

Iron from foods such as meat, liver, eggs, green vegetables and fruits are absorbed in the small intestine. The average of foods included contains $10-15 \mathrm{mg}$ of iron but only $5-10 \%$ which can be absorbed, so if the decrease in iron intake is the main element in the formation of hemoglobin, the level/production of hemoglobin will also decrease and causing anemia (10).

\section{Pregnancy Distance in Pregnant Women}

Pregnancy distance is the interval between two consecutive pregnancies from a woman. Pregnancy spacing has an impact on the health of the mother and her baby. The distance of pregnancies that are too tight ( $<2$ years) is riskier than a stretchy pregnancy ( $>2$ years). This is because anatomically women need time to restore their health and adequate nutritional intake. The results of relationship analysis using the Chi-Square test of df (Degree of Freedom) 1 and $\alpha=0,05$ were obtained $p=0,001$ where $p$ $<\alpha$ which means statistically the null hypothesis is rejected and the alternative hypothesis is accepted so that there is a significant relationship between pregnancy distanceand the incidence of anemia in pregnant women at the Anutapura
Hospital in Palu. This is in line with the study conducted by Dewi (2010), that pregnancy distance is related to the incidence of anemia in pregnant women at Batua Raya Makassar Health Center with P-value 0.002.

\section{Antenatal Service in Pregnant Women}

DepartemenKesehatan RI (2011) in antenatal care consisting of weighing, checking blood pressure, checking fundus uterine height, tetanus toxoid injection (TT) and giving $\mathrm{Fe}$ tablets, PMS tests, and interview. This service should be carried out regularly by pregnant women until they give birth.

Antenatal examinations are services by professional staff (midwives) to pregnant women during pregnancy that are carried out following established standards. The antenatal examination is recommended at least four times during normal pregnancy conditions, but the reality in the field, especially in AnutapuraPalu General Hospital, there are still many pregnant women who do not regularly check their pregnancies to health facilities that have been prepared by the government so that the impact on some pregnant women is anemia.

The results of relationship analysis using the Chi-Square test of df (Degree of Freedom) 1 and $\alpha=0,05$ were obtained $=0,002$ where $p<$ $\alpha$ which means statistically the null hypothesis is rejected and the alternative hypothesis is accepted so that there is a significant relationship between the use of antenatal service and the incidence of anemia in pregnant women at the Anutapura Hospital in Palu.

What applies in this study is that the more often pregnant women make use of antenatal care, they are less likely to have anemia and vice versa. But the better the antenatal care of pregnant women, the smaller the possibility of anemia, and vice versa where antenatal services are less likely to have anemia. 


\section{CONCLUSION AND RECOMMENDATION}

Based on the results of data analysis/ discussion about the relationship of parity, maternal age, Fe tablet consumption, pregnancy distance and antenatal care with the incidence of anemia in pregnant women on March 18 April 18, 2015, at Anutapura Hospital in Palu, it can be summarized as follows: There is a relationship between parity and the incidence of anemia in pregnant women atAnutapura Hospital Palu; There is a relationship between maternal age and the incidence of anemia in pregnant women at the Anutapura Hospital in Palu; There is a relationship between consumption of $\mathrm{Fe}$ tablets and the incidence of anemia in pregnant women at Anutapura Hospital in Palu; There is a relationship between the distance of pregnancy and the incidence of anemia in pregnant women at the Anutapura Hospital in Palu; There is a relationship between the use of antenatal care and the incidence of anemia in pregnant women at the Anutapura Hospital in Palu; Factor consumption of Fe tablets is the most associated with the incidence of anemia in pregnant women at the Anutapura Hospital in Palu.

\section{REFERENCES}

1. Adisasmito. 2011. Gizi dalam DaurKehidupan. Penerbit Buku Kedokteran EGC. Jakarta.

2. Ari Madi Yanti D, Sulistianingsih A, Keisnawati. Faktor-Faktor Terjadinya Anemia pada Ibu Primigravida di Wilayah Kerja Puskesmas Pringsewu Lampung. J Keperawatan [Internet]. 2015 [cited 2017 Dec 25];6(2):79-87. Available from: http://download. portalgaruda.org/ article.php?art icle $=424747 \& \mathrm{val}=278 \&$ title $=$ Faktor-Faktor Terjadinya Anemia Pada Ibu Primigravida Di Wilayah Kerja Puskesmas Pringsewu Lampung

3. Arisman. 2010. Gizi dalam Daur Kehidupan. Bagian IImu Gizi Proyek Peningkatan Penelitian. DIKTI Depdiknas. Fakultas Kedokteran USRI, Palembang.
4. AzisAlimut Hidayat.2010.MetodePenelitian Kebidanan Tehnik Analisis Data.Penerbit Salemba. Jakarta

5. Budiarto, E. 2012. Biostatistik. EGC, Jakarta.

6. Budiarto, Eko dan Dewi Anggraeni, 2012. Pengantar Epidemiologi. Penerbit Buku Kedokteran. EGC. Jakarta.

7. Departemen Kesehatan Kota Palu,2011, Profil Kesehatan Kota Palu

8. Departemen Kesehatan Propinsi Sulawesi Tengah, 2011. Profil Kesehatan Kota Palu.

9. Hasbullah. 2008. Dasar-dasar IImu Pendidikan. Graja Grafindo Persada. Jakarta

10. Herawati C, Astuti S. Faktor-Faktor yang Berhubungan Dengan Anemia Gizi pada Ibu Hamil di Puskesmas Jalaksana Kuningan Tahun 2010. J Kesehat Kartika [Internet]. 2016 [cited 2017 Oct 24];51-8. Available from: http:// www.stikesayani.ac.id/publikasi/e-journal/fi lesx/2010/201012/201012-007.pdf

11. Husnawati F. Analisis Faktor yang Mempengaruhi Tingkatan Anemia pada Ibu Hamil Anemia di Pusskesmas Sentolo II Kulon Progo [Internet]. Universitas 'Aisyiyah Yogyakarta; 2015 [cited 2017 Oct 24]. Available from: http://digilib.unisayogya. ac.id/209/1/FARIDAH HUSNAWATI NASKAH PUBLIKASI.pdf

12.I Made Bakta. 2012. Hematologi Klinik Ringkas.EGC.Jakarta

13. Idayati, 2012., Beberapa Faktor Risiko Kejadian Anemia Pada Ibu Hamil di Wilayah Kerja Puskesmas Hasanuddin Kabupaten Maros PeriodeJanuari-November 2012, Tesis PPs Unhas, MaKassar.

14. Manuaba IBG, 2010, IImu Kebidanan Penyakit Kandungan dan Keluarga Berencana, EGC, Jakarta

15. Mochtar, 2009. Sinopsis Obsetetri Fisiologi Patologi. Jilid I. Buku Kedokteran EGC. Jakarta.

16. Muchtadi, Dedy. 2010. Pengantar IImu Gizi. Alfabeta. Bandung. 
17. Notoatmodjo, Soekidjo 2010.Pendidikan Dan Perilaku Kesehatan, PT.Rineka Cipta; Jakarta

18. Notoatmodjo, Soekidjo 2012.Metodologi Penelitian Kesehatan. Edisi Revisi. Penerbit Rineka Cipta. Jakarta

19. Notoatmodjo, Soekidjo2012. Pengantar Pendidikan Kesehatan dan IImu Prilaku, Jakarta, Rineka Cipta.

20. Nurhasiba, 2010.Faktor-Faktor Yang Berhubungn Dengan Kejadian anemia di Puskesmas Bajo Desa Sampa Kecamatan Bajo Kabupaten Luwu Tahun 2006, Tesis PPs Unhas, Makassar.

21. Prawirohardjo Sarwono, 2009., Buku Acuan Nasional Pelayanan Kesehatan Maternal

22. Purwadarminto.2011. Kamus besar bahasa Indonesia, Balai Pustaka. Jakarta
23. Rasnah, 2012.Faktor-Faktor Yang Berhubungan Tentang Status Kelengkapan Imunisasi TT pada Ibu Hamil Di Puskesmas Bajeng Kabupaten Gowa, Tesis Unhas, Makassar.

24. Ratna Hidayanti. 2009. Asuhan Keperawatan Pada Kehamilan Fisiologis Dan Patologis. Salemba Medika. Jakarta

25. Saifuddin, A.B. 2012. Buku Panduan Praktis Pelayanan Kesehatan Maternal dan Neonatal. Yaysan Bina Pustaka Sarwono Prawihardjo. Jakarta

26. Varney, Helen. 2012. IImu Kebidanan Edisi 4. Sekeloa Publisher. Bandung.

27. Wiknjosastro, H. 2008. IImu Kebidanan. Yayasan Bina Pustaka Sarwono Rawihardjo. Jakarta

28. YuniKusmiati. 2008. Perawatan Ibu Hamil. Pitra Maya. Yokyakarta 